\title{
Comparison for Curriculum Ideologies
}

\author{
Saleh Alanazi \\ Curriculum and Instruction department, College of education \\ St. Louis University, USA \\ al-mosafer-s@hotmail.com
}

\begin{abstract}
The article starts by defining school curriculum then describing different ideologies that are included in the school curriculum. The past learning ideology is compared with the present learning style. The paper goes ahead to provide a comparison between the two ideologies of the school curriculum. The author proceeds to provide the purpose and significance of school curriculum in the learning institutions. More specific is the description of the underlying beliefs that the learner has about the past and the present curriculum ideology.

In the next explanation are the assumptions of the learner-centered ideology on explaining the student knowledge. The learner-centered ideology offers the relationship between the students and teachers. The article also describes the assumption of the social efficiency about knowledge of the learner. The author offers the learning conditions basing his argument on the two ideologies. Lastly is the explanation of the stages of developing school curriculum in special education and a final conclusion of the paper.
\end{abstract}

Keywords: Curriculum Ideologies, School Curriculum, Social Efficiency, Learner-Centered, Learning Ideologies, Special Education Curriculum, Different Grade Curriculum and Past Education Curriculum

\section{INTRODUCTION}

Critical approach to education is all about the need to value individual talents differently. Today, every country on earth is reforming its public education. For many years, educators have been exploring and examining different ideologies on school curriculum with an aim of determining the best fit for learners. Underlying this exploration are two basic ideologies explaining the nature of school curriculum. The two advocate very different purposes for the same. However, this paper compares two ideologies which are learner centered and social efficiency ideologies. In many ways, these two ideologies have motivated improvement in American schools even though some scholars argue they also have conflicting standpointson development of better curriculum.

Curriculum is a term referring to what is taught in schools or even a specific course or program undertaken by students (Vars, 1991).Traditionally, school principals were just placing teachers in classroom, provide textbooks and have teachers guide their students through class work, today's curriculum is more than that. This is true because most people are not really aware of their capabilities and what they can achieve. Most of them go to school to learn about things they do not know and to fulfill their basic need which is "education." However, they do things they feel about as more competent or in other words things they feel they need to do, but do not do them under great passion, commitment or great sense of fulfillment.

In the past, teachers' performance was judged on their ability to produce "better students." Today, educational system requires teachers to have in-depth knowledge of what they need to teach their students not only to fulfill their educational needs but also to help them know their capabilities and talents (Vars, 1991).Accordingly, educators need to know and understand what exactly they need to teach their students. This means they 
need to be skilled enough to determine whether or not they give their students the knowledge, skills, and the understanding they need to acquire as per their core curriculum.

Given the fact that every country has a different educational system, educators need to be determined to know about educational national standards in both academic courses and elective fields of study such as fine and practical arts so as to identify the most important standards they can follow when creating school curriculum. In other words, teachers should know "covering everything learning nothing" is a wrong approach towards any core curriculum.

\section{The Purpose for CuRriculum}

The purpose for developing well informed curriculum is to ensure that educators know what they need to teach their students. Curriculum set down goals, objectives, instructional resources to be used when teaching and learning. It also communicates what students should know, do, and enable teachers to achieve goals and objectives set forth in the curriculum. Other purposes include:

(a) Establishes clear picture of goals that guide the entire learning and decision-making that affect each area of learning.

(b) Curriculum establishes learning sequences and assures an informed learning progression from one level to the other.

(c) It outlines a basic framework for what teachers should teach, how students should tackle their school work, when to do it, and how to know if goals and objectives have been achieved.

(d) Allows for flexibility within different time frames hence promoting experimentation and innovation when and where necessary

(e) It also encourages interdisciplinary advances among both students and teachers.

Vars (1991) explain that today educators are seeking ways in which they can help students to make sense out of real life situations by developing integrative school curriculum focuses on student's concerns. Here, Vars (1991) argues well informed curriculum is the one that encapsulates the following four capacities- enables students to be successful learners, one that helps them become confident on what they can do, become responsible learners, and become effective contributors in everything they do. These four capacities try to elucidate that school curriculum should aim at helping students to develop knowledge and skills they will use in their future endeavors.

That said, the following is a concise comparison of the two ideologies developed to explain how and what to consider when developing school curriculum.

\section{UNDERLYING BELIEFS ABOUT LEARNER CENTERED IDEOLOGY}

According to MacHemer et al, 2007, p.g; Boyer, 1990), learner centered ideology is a phenomenon that puts the learner at the center. When teachers begin their career in teaching, most of them are probably not confident and familiar with the methods they are likely to use and, therefore, are concerned about how the students are likely to perceive them. In such a case, teachers tend to be more focused on performance rather than on learners' response to the lesson. As teachers become more experienced and more confident, however, they are able to switch to a motive teaching which gives more focus on the learners.

It is easy to see this in for example, the extent to which teacher talking, dominates the classroom as opposed to learner participation. Therefore, learner centered classroom is one in which the teacher role is minimal or in 
which the teacher finds ways of engaging students. It also involves ways in which teachers make connections to the student's personal lives through the content of the lesson and letting students take as much responsibility for learning as possible.

According to learner centered ideology, educators should develop school curriculum that allow students to become active participants in a more engaged in the content in the lesson and have more choice on what they want to do and how to do it.

\section{LEARner CENTERED AsSumption ABOUT KNOWLEDGE}

\section{Schools are places where students are helped to develop and discover their innate capabilities}

Those advocating for learner centered ideology do not belief on the needs of the society or the academic prospects, but on individual interests. According to Schiro (2008), schools should be places where individual enjoy as they acquire knowledge and develop their inherent capabilities. Traditional curriculums were developed to guide students on how to solve problems but a new approach that focuses on individual development is important. The ideology of learner centeredness should be initiated to improve students' capabilities and to reduce the avoidable failure of not helping students discover their strengths (Lave\& Wenger, 1991).

What this means is that the goal of education should be viewed as a way of helping individuals to develop their innate abilities they can use in their future endeavors. A good school curriculum gives students an opportunity to discover their innate capabilities. According to Schiro (2008), students do their best when they are allowed to do what they like most and school can be a better turning point if only they help students to discover the so called innate capabilities.

The idea is palpable in day to day life and it can be used to make individuals realize individual values. Its advocates believe that every human being has an innate capability to do something incredibly and differently. They also believe that with the right conditions, inherent capabilities will no longer be something laying inside oneself but something that will help individuals to achieve what they yearn to achieve in life. In relation to that, Schiro talks about credibility that depends on individual passion or personal interest explaining that education should be treated as something that helps students to draw their innate capabilities rather than being a system that shows them only how to solve problems. Therefore, school curriculums should be based on what individuals are passionate about and what they find worthwhile. In other words, school curriculum should be a facilitator of healthy, virtuous, and beneficial growth. This is only possible if strengths are naturally coaxed out of student's innate capabilities (Schiro, 2008).

In this context, school curriculums should persuade students to engage themselves in learning by asking questions creatively along a wide range of subjects. This allows them to become creative thinkers who are capable of imagining and exploring alternatives they have in their exposure. Such an approach is essential for a firm academic foundation that enhances learner's knowledge and skills including soft skills such as in-depth understanding of what they are taught in class as well as improved communication skills.

Learner centered ideology indicate that learning is enhanced by good relationship between students and teachers (Lave \& Wenger, 1991). For students to learn and discover their innate capabilities, they need unlimited time to explore their interests. This has profound advantages of helping individual student to develop critical reasoning skills. Therefore, learner centered ideology require school systems to develop curriculum that strategizes and supports educational goals that ensures freedom of learning and teaching. 


\section{SOCIAL EFFICIENCY ASSUMPTION ABOUT KNOWLEDGE}

\section{Schools are places where students are helped to develop skills they can use to fulfill social needs in the society}

According to social efficiency, teachers decide what students are supposed to learn, why they are learning it, how they are supposed to learn it, what assignments they will be doing as well as what books they will be reading. Essentially, the teacher controls everything in the classroom. In this context, schiro (2008) explain that social efficiency is an ideology that allows schools or educators to be in control of everything their students does and is characterized by power, control and efficiency.

Unlike learner centered ideology, social efficiency focuses on teachers helping students to develop skills essential for society needs. Here, the student is viewed as potential member of the society with required capabilities to do everything taught in the classroom. However, this ideology holds that teachers should more importantly place their focus on helping students to develop skills they can use to fulfill social needs.

Unlike learner centered ideology, social efficiency believes that the initial aim of learning is to meet social needs of the society. Educators who use this ideology view school curriculum as a tool that prepares students to become contributing members of the society hence supporting the assumption school is a place where students are prepared to meet social needs.

However, Schiro argues that the central concern of social efficiency is based on scientific instrumentalism whose concern argues that educators should develop school curriculum designed in a scientific manner in order to fulfill the needs of the society. The first milestone is to determine the needs of the society and then develop a curriculum that meets determined needs. Then, educators find the most efficient method of passing on acquired knowledge to the learners with an aim of producing "educated people" who meets the objective of the developed curriculum and who fulfills the needs of the society (Schiro, 2008).

\section{CONDITIONS FOR LEARNING}

\section{School Curriculum should facilitate students to interact with their physical environment}

Learner centered ideology view classroom as a place where learners are motivated to develop their innate capabilities. However, the classroom is where learners gain profound understanding of their position in the world and what they can present to it when they are through with their learning. Classroom is where learners shape their future in a way they want it to look like by acquiring knowledge they can use to reach that goal. However, with the classroom being an important element of discussion in this study, it is crucial to have a well understanding on how various things can affect learning environment. Because educators play an important role in helping learners to develop their innate capabilities, they should also ensure that learning environment helps students thrive in everything they do.

If educators happen to approach learning environment wrongly, then they are likely to stifle learner's creativity or even fail to promote positive learning environment. In support, Schiro (2008) emphasizes that learning should therefore, be considered as a function of the interaction between a person and his or her environment. This inference demonstrates that a school curriculum that supports student-environment interaction shapes student's learning because it responds to student's needs (Oliver \& Lippman, 2007).

However, educators researching on learning environment have been having crucial debate on why it is important to have a school curriculum that supports favorable learning environment. In their discussion 
they have noted that good learning environment shapes the learner and in turn the learner enjoys learning something that improves her/his overall performance. Therefore, there is an existing transactional relationship between learning environment and student's performance in school. It is for this reason that Lave \& Wenger (1991) explain educators must develop profound understanding towards this relationship to ensure that when developing school curriculum they put into consideration factors motivating students to learn with respect to environment in which they seek to acquire knowledge. To this extent, it is clear the learning environment in this context is composed of the students, teachers, and the physical environment.

Learner centered ideology requires educators to design school curriculum that envision school as a place where students engages in self-directed and co-operative learning activities. Dent-Read \& Zukow-Goldring (1997) explain that in the constructive setting, students learn from their own discoveries, whereas with practice theory learners are transformed and shaped by their transactions alongside others and their physical settings. Therefore, it is for this reason that learner centered ideology requires educators to design school curriculums that support favorable physical environment to ensure that students enjoy learning while they make their own discoveries.

Learner centered ideology aspire students to engage in different activities to extend their innate capabilities and development beyond their current capabilities and knowledge. On the whole, the aim of this prospect as applied in learner centered curriculum is to foster critical thinking, social skills through co-operative activities and self-directed work. It is for this reason that learner centered curriculum should have physical environment integrated because it is the "third teacher" who guides learning and it must be well organized to foster learning opportunities.

To foster learning opportunities, learner centered ideology requires educators to develop or design school curriculum that encourages students to explore their learning environments through self-directed and what is well known as "co-operative" learning activities. In modern education, this is a new approach integrating things like technology in learning. Traditionally, things like films, radio, televisions and videos were used to foster learning opportunities (Oliver, 2004); today, technology has taken education to the next level as things like computers, tablets, SMART boards have been introduced into the instructional settings. The problem is that neither traditional nor current technologies are being fully utilized or even integrated into school curriculum as learner centered ideology anticipates (Weiss, 2007).

One reason related to the above problem is that many educators design school curriculum that does not support the integration of technology (Oliver and Lippman, 2007; Weiss, 2007). Learner centered ideology holds that learning environments should be designed in a way that supports school curriculum that also supports intended learning activities. Over decades, majority of schools have barely changed their classroom settings making it difficult for the adaptation of new learning environments. Therefore, learner centered ideology assumes that in order to foster favorable learning environment, schools need also to change traditional culture they hold dear of their classrooms (Weiss, 2007). By so doing, educators keep learners engaged by allowing them to be successful within their learning environment.

\section{Social Efficiency:School Curriculum should facilitate students to interact with their physical environment}

American educator well known as John Dewey viewed education is a social process (Dewey, 1897). He held that students tend to learn well and develop profound willingness to learn when they interact with each other 
in a rich environment (Mooney, 2000; Rushton \& Larkin, 2000). Through the responses they receive from the surrounding environment, learners connect educational value and social meanings to school activities. It is for that reason that Dewey required that educators develop school curriculum that helps to organize learners as a community in which they learn in cooperation with each other and their teachers.

Russian psychologist Lev Vygotsky concludes that social interaction and a positive learning environment is crucial to student's learning (Vygotsky, 1978). In relation to social efficiency ideology, Vygotsky (1978) thinks that learners need to have an environment that allows them to talk and share about different problems they encounter when learning. In this aspect, he talks about "zone of proximal" development to explain the wide range of learner's ability to acquire knowledge about a particular experience. According to him, the lower zone represents what a child can do independently, the upper zone represents what a child cannot do alone or rather what the learner can do with the help of others.

The process of helping students build knowledge in a rich environment can be viewed in the lens of a scaffold trying to reach a high roof. A supportive environment helps the learner develop skills at a higher level than he or she could have done when learning in a non supportive environment. Teachers involvement in giving instructions and direction on what learners need to do and how to do it help learners to figure out how to handle pressing matters as well as how to approach learning tasks and develop the ability to improve their skills. In relation to that, Vygotsky believes that educators should curriculum that promotes methods teachers can use to assist learners to ensure they internalize what they are being taught in a more mature thinking. By so doing teachers will understand learners' level of learning and find ways to extend their learning in a better way.

Recent research indicates the importance of teacher-learner relationships (Rudasill \& Rimm-Kaufman, 2009). Advocates of social efficiency believe that learner's ability to form positive relationships with their teachers is significant to their social development and helps them to thrive academically (Bronson, 2006; Howes, 2000; Paleromo, Hanish, Martin, Fabes \& Reiser, 2007). To this extent it is clear social efficiency do not only provide a context for learning, but affect the physical structure of the learner's social life both in school and outside the school. The extent of these relationships helps in predicting learner's social-emotional competence, persistence, enthusiasm for learning and academic excellence (Clifford, et. al2005).In addition, advocates of social efficiency argue that curriculum that supports social interaction between learners and teachers benefit learners in spite of their social background and as well as economic status. This interaction promotes positive development of academic skills as relative to what learners are supposed to be taught.

According to learner centered ideology, supportive relationship between students and teachers make learners to be motivated, to engage in whatever they are learning, promote self-direction, cooperation and positive attitudes towards learning environment (Birch \& Ladd, 1997).

On the other hand, advocates of social efficiency argue that supportive relationships with educators can help learners to overcome challenges they experience in life as well as in new learning environments. Research on curriculum flexibility has shown that learners who develop intended skills tend to adapt well in social life regardless of hardships they encounter. This assumption is significant because it supports social efficiency ideology that learners who learn and develop under harsh conditions are likely to encounter hardships in their future life. Research on social efficiency has shown that learners can develop the strengths and skills required to deal with social problems. Various studies on social efficiency are being conducted to provide more 
information about curriculum development that supports learners' educational needs they need so as to thrive in their academic endeavors. This is not surprising because these studies also note the importance of developing curriculum that promotes equality in education offered to learners with special needs and normal students.

\section{CURRICULUM DEVELOPMENT IN SPECIAL EDUCATION}

The issue of equality in the education offered to children with special needs, and normal children have been emphasized over and over again. The No Child Left Behind Act (NCLB), The Every Student Succeeds Act (ESSA) and the Individual with Disabilities Education Act (IDEA) all seek to ensure that people with disabilities are given equal learning opportunities. These national regulations explicitly state the need to ensure that children with special needs access a similar level of education as their peers in the normal school system. This ensures that these children do no lag behind regarding the knowledge they acquire in school. This is despite the challenges they face. It also prepares them to compete fairly with other children, as they grow up learning similar things and as such are in a position to fit in the world after school (Bateman \& Bateman, 2014). This essay discusses how a teacher can ensure that he or she observes the philosophies of social justice, equality and high anticipation in educating students with disabilities.

Many children with disability have accomplished beyond expectation. This is after provided with the right opportunities and support they require in the course of their studies. Education is a universal right that every child needs to access. Therefore, to ensure that children with special needs are not left out, there has been the formulation of Special Education Laws. These laws ensure that children with a disability receive the education that matches that offered to children in the normal education system. Most of these laws emphasize the need for the education to match the needs of the child. This prepares the child to handle difficulties that might arise in the course of his or her life. It also increases the chances of success for the child with a disability in the attainment of his or her goals in life (Bateman \& Bateman, 2014).

It is necessary for teachers to manage the learning environment proactively when dealing with children who have special needs. This minimizes behavior challenges and promotes learning among these children. Nonetheless, it is hard to ignore the fact that most of these children will still lack regarding their social interactions with other children, or even in their learning because they might lack the special skills they require to grasp different concepts in school. It is, therefore, the duty of the teachers to ensure that the curriculum of these students lays much emphasis on skill training in the deficit areas of these students (Smith, et al. 2015).

One of the most effective techniques for teaching children with disabilities how to be independent in life is the use of visual cues. Visual cues help guide the students through the physical space of their classrooms. For example, the teacher can use markers to mark boundaries and ensure that books and other learning materials are stored inaccessible shelves. This is especially the case in a situation where the classroom is being used for multiple purposes. The use of markers to show boundaries helps these children identify when they are in a zone meant for playing and when they are in a section meant for learning. This develops their sense of the need to plan time and the importance of carrying out activities at a given time and environment (Yudof, et al. 2011).

Just like the children in the regular education systems, children with disabilities also crave predictability and structure in their education schedules. Therefore, it is necessary to ensure that these children are given predictable and well laid out education schedules. The daily routine should follow the same order every day, which makes it easier for the child to adapt to keep to the schedule. Lessons should be allocated the same amount of time, and there should be breaks in between for them to relieve themselves or take snacks. It is 
also necessary to ensure that in the creation of the schedules the teacher considers the child's skill level. An individual based schedule can also be prepared for students who require extra services or support. This ensures that they do not miss on anything that children in the regular education system get in the process of their learning process (Smith, et al. 2015).

Motivation plays a crucial role in the education process of children in the special needs program and even those in the regular education system. It is the driving force behind learning and as such the teachers in a special education program need to ensure that they constantly build motivation. This increases the desire in their students to learn new concepts and even practice the skills they are taught in school. In the process, the teacher should also evaluate the pace at which the student in learning new concepts. This helps in varying the learning activities to ensure the child learns as per his or her level of understanding (Salvia, Ysseldyke \& Bolt, 2012).

Finally, it is important to evaluate regularly the learning progress of the students in a special needs program. This helps identify the weak areas that require the teachers' and parents' attention. Regular assessment of the student together with the other activities mentioned in this essay ensures the child learns in an almost similar if not the same learning environment as students in the standard education system (Aron \& Loprest, 2012).

\section{TeACHeRs Roles in CURRICUlum DeVELOPMENT}

According to learner centered ideology, a capabilities approach to education considers how the individual in his or her context can lead a life that she or he has reason to value. Learner centered ideology argues that acquiring "powerful" knowledge through what is taught by teachers in classroom is of fundamental value to developing "capability." This requires thinking about the role of teachers. Learner centered ideology asks teachers to consider their role and their teaching methods in helping learners reach their full human potential because a capable person is autonomous.

However, teacher participation in the curriculum development process is essential whether it is in the definition of problems or the presentation of concrete solutions to issues facing learning environments. This paper approaches the role of teachers in curriculum development in double role for teachers. Teacher's role in the curriculum development has been widely discussed. Based on his review of the literature, Connelly (1972) concluded that teachers are highly autonomous agents with respect to externally developed curriculum materials.

Teachers are competent professionals whose active involvement in curriculum development is crucial for successful learning and teaching strategies. Sometimes, teachers are limiting factors in the curriculum process as far as their flexibility in the adoption of innovations and their readiness to learn new materials and new ways of teaching are concerned. Only rarely are teachers' own interests and concerns are allowed to influence or direct the choices made by curriculum developers. Yet, without active teacher involvement, curriculum development may turn out to be futile and ineffective. Researchers suggest that "educational research and development is effective when the nature of the problem and of the solution is deliberated by practitioner and researcher together, on a basis of equal status, respect and substantive contribution (Vygotsky, 1978)." Teachers are thus seen as important elements in curriculum development which is a process that starts with the definition of a curriculum problem and ends with the development of a curriculum solution.

There are two ways in which teachers are involved in curriculum development. They include (a) teachers should be involved in "external' development of school curriculum developed outside the school or the classroom and (b) they should be involved in the continuation process of adapting and in development of teaching and 
learning materials thus allowing them to function as "material developers (Connelly, 1972)." It is also important to note here that during the development process of school curriculum, classroom teachers are assigned the responsibility to construct learning and teaching materials. The result of this process is designed to ensure flexible implementation in various educational settings. The following is a well structured guideline for curriculum development. The guideline is relative to the two ideologies discussed along this paper.

This guideline principle stems from both learner centered and social efficiency ideologies on curriculum development. Learner centered ideology emphasizes the need for developing ways that allow learner, teacher, and subject coordination in curriculum deliberations. This co-ordination is essential for valid educational thought. In this view, subject matter of the content to be taught in schools and the nature of the anticipated learner are the main sources for curriculum development that should be put into account by curriculum developers.

\section{Summative Conclusion}

The relation between the two curriculum ideologies reveals each curriculum ideology as the effect of emphasizing two causes. Learner centered ideology is critical in emphasizing the need for adapting teaching system that focuses on learners over any particular social purpose. The social efficiency ideology stresses the importance of the social purpose or what educators refer to as final cause above any learner concern. The learner centered ideology highlights the importance of learner innate capability in a future sense, with less concern for traditional educational systems while social efficiency ideology emphasizes on this traditional or what is well known as "formal cause" to the detriment of unfolding learners capability.

\section{REFERENCES}

Aron, L., \& Loprest, P. (2012). Disability and the education system. The Future of Children, 22(1), 97-122.

Connelly, F. M. (1972). The functions of curriculum development. Interchange, 3(2-3), 161-177.

Bateman, D. F., \& Bateman, C. F. (2014). A principal's guide to special education. Council for Exceptional Children.

Birch, S. H., \& Ladd, G. W. (1997). The teacher-child relationship and children's early school adjustment. Journal of School Psyhcology, 35, 61-79.

Bronson, M. B. (2006). Developing social and emotional competence. In D. F. Gullo (Ed.), K Today: Teaching and learning in the kindergarten yer (pp. 47-56). Washington, DC: National Association for the Education of Young Children.

Clifford, R. M., Barbarin, O., Chang, F., Early, D. M., Bryant, D., Howes, C., et al. (2005). What is pre-kindergarten? Characteristics of public pre-kindergarten programs. Applied Developmental Science, 9(3), 126-143.

Dewey, J. (1987). My pedagogical creed. In J. Dewey \& A. W. Small, Teachers manuals (No. 25). New York, NY: E.L. Kellogg \& Co.

Howes, C., Burchinal, M., Pianta, R., Bryant, D., Early, D., Clifford, R., et al. (2008). Ready to learn? Children's pre-academic achievement in pre-kindergarten programs. Early Childhood Research Quarterly, 23, 27-50.

Lave, J. and E. Wenger (1991), Situated Learning, Cambridge University Press, New York. 
Mooney, C. G. (2000). Theories of childhood: An introduction to Dewey, Montesorri, Erikson, Piaget \& Vygotsky. St. Paul, MN: Redleaf Press.

Oliver, C (2004), "Teaching at a Distance: the Online Faculty Work Environment", unpublished dissertation, The City University of New York, New York.

Oliver, C. and P.C. Lippman (2007), "Examining space and place in learning environment", paper presented at the CONNECTED International Conference on Design Education, 9-12 July, University of New South Wales, Sydney, Australia.

Rudasill, K. M., \& Rimm-Kaufman, S. E. (2009). Teacher-child relationship quality: the roles of child temperament and teacher-child interactions. Early Childhood Research Quarterly, 24, 107-120.

Ruahton, S., \& Larkin, E. (2001) Shaping the learning environment: Connecting developmentally appropriate practices to brain research. Early Childhood Education Journal, 29(1), 25-33.

Salvia, J., Ysseldyke, J., \& Bolt, S. (2012). Assessment: In special and inclusive education. Cengage Learning

Smith, T. E., Polloway, E. A., Patton, J. R., Dowdy, C. A., \& Doughty, T. T. (2015). Teaching students with special need in inclusive settings. Pearson

Vars, G. F. (1991). Integrated curriculum in historical perspective. In Abstracts International (Vol. 20, pp. 1830-1831).

Vygotsky, L. S. (1978). Mind in society: The development of higher psychological process. Cambridge, MA: Harvard University Press. (Original work published in 1934).

Weiss, A. (2007). "Creating the Ubiquitous Classroom: Integrating Physical and Virtual Learning Spaces, in the International Journal of Learning, Vol. 14, No 3, www. Learning-Journal.com.

Yudof, M. G., Levin, B., Moran, R. F., Ryan, J. E., \& Bowman, K. L. (2011). Educational policy and the law. MSU Legal Studies Research Paper, (09-15)

Citation: Saleh Alanazi, "Comparison for Curriculum Ideologies". American Research Journal of Humanities and Social Sciences, Volume 2, 2016; pp:1-10

Copyright (c) 2016 Saleh Alanazi, This is an open access article distributed under the Creative Commons Attribution License, which permits unrestricted use, distribution, and reproduction in any medium, provided the original work is properly cited. 